\title{
Colouring Rhetoric
}

\author{
Barbara Godard
}

Application? Implication? How to map the interaction of verbal and visual signs? Are these relations of reference, or figuration, or sign type? Do pictures illustrate texts augmenting the word's referential powers? Through juxtaposition, the truth-telling claims of painting's mirroring status would attribute its reality effect to writing. Conversely, does the word fix the polysemic or connotative meanings of a visual image, loading it with cultural value (Barthes 26)? When verbal and visual images coexist in a text does each function as referent for the other or does one mode of apperception interrupt another? Is rhetoric coloured (Steiner) so that words are viewed iconically, concretely as pictorial objects, and visual lines or colours read indexically as indicating some object? What sort of semiotic slippage may ensue? What modalities of the threshold or liminality does this reading one type of sign through another, or passing between, engage? Does it make a difference if the moving pen or perceiving eye is guided by a woman? What is the colour of her speech (Tostevin)?

Questions of this sort are very much on the agenda of contemporary culture which has been characterized by its "oculocentrism": modern and postmodern society have privileged the sense of sight producing a multiplicity of scopic regimes (Gandelman 151). One manifestation of this hegemony of the eye is in the renewed importance of the venerable painting-literature analogy which has emerged in the twentieth century following Romanticism's preoccupation with the expressive rather than mimetic capacity of art. In reasserting itself, however, the analogy is reversed, no longer stressing the mirroring status of art but staging the tension between artistic medium and represented world dialectically or dialogically to underline the "paradoxical status" of both word and visual image as "signs of reality" (Steiner xii). Growing attentiveness to the double existence of the word as a pure shape and as a non-sensory medium for producing sense has resulted in a focus on the semiotic 


\section{Tessera}

concreteness of language as res poetica and, conversely, in an exposition of the mediated or semiotic nature of visual art, no longer revelatory of what is "truly" ("naturally") (t)here. Capable of connection in a "continuous contexture" (Steiner 7) these aesthetic signs are dynamically related.

The hegemony of the eye in the twentieth century has been articulated paradoxically. Celebration of the gaze is phrased in terms of the trauma of sight: the fetishizing of the eye signals the end of vision (Gandelman 150). Surrealists concerned with provoking the castrated eye of convention resorted to "the brutal truth of visual violence" to uncastrate it (Gandelman 156). This imagery of castration reveals an obsession with the eye as a quasi sexual organ, conception crystallized by Jacques Lacan in his theory of the "scopic function" that concretized the analogy between the act of visual apperception, the gaze, and a sexual act, building on Freud's analysis of the blinding of Oedipus as an act of self-castration. Apperception is understood as a thrust or drive of the eye toward a sexual object, active in ordinary vision but especially constitutive of the self or subject through the mirror phase in which the child enters the "Imaginary" stage of self-constituting through the power of the eye in the mirror. The subject is constituted thus as the image of an image in the specularity introduced by representational splitting where the child becomes the object of its own gaze, image projected outside the self to form an illusory and visual unity that determines all future relations with objects, all future relations of desire as those of subject-object relations.

Against this model of identification in terms of vision, Kristeva reworks the Freudian theory of an affective relation with another, an intrusion of an affect into the self that precedes the opposition spectaclereceptivity. Central to this theory of primary narcissism is the ubiquitous character of amorous relations in which each subject gains satisfaction from the love object to the extent that it is in narcissistic relation to that object. This ubiquity is not originary, according to Kristeva, but is the result of a "new action" prior to the Oedipal Ego and supplementary to the auto-eroticism of the mother-child dyad: it is the introduction of a third, the imaginary archaic Father, with whom the child identifies not as with an object in a relation of having (as in a secondary identification of a sexual order), but in a dynamic and "metaphoric" identification of "being-like" (Kristeva 1983,38-39). This metaphor constitutes a relational not referential dynamic, a movement toward a subject ideal (Kristeva 
1983,35). This phase constitutes the mother as "ab-ject" in the first effort of the subject to separate from the pre-oedipal mother before the mother becomes correlative to the Ego's desire (Kristeva 1983, 45). It figures the flux or exchange of affect among non-subjects, non-objects.

There is always a danger that the subject will remain a non-subject, merely the "shadow of a non-object" (Kristeva 1983, 40-41). Nonetheless, Kristeva postulates that it is through this non-objectal identification that the psychoanalytic cure may be mobilized as an exchange of love (Kristeva 1985,9). While Kristeva's theory of identity displaces the work of the gaze in favour of a transference and counter-transference occurring through the word or talking cure, the binary gender relations of the scopic regime remain. No longer a woman's phallic eye to be countered by a man's phallic index finger in a horn-gesture (Gandelman 157), but a social narrative in which the oedipal scenario prohibiting the feminine, figures prominently nonetheless. Within this dominant model, as lesbian theorists have pointed out (Parker), relationships of love are invariably heterosexual. The model of self and alterity on which the relations of identification and transference are constructed presupposes male-female relations of desire. Kristeva's model of identity may offer an alternative to the hegemony of the eye, but it does not dislodge the primacy of the law of the Father as the arbitrator of relations of desire and of meaning. Such a project is, however, at stake in the following essays.

Visual and verbal signs interact in a number of ways in the texts for this issue of Tessera. The verbal tissue of the prose and poetic texts of Claudine Potvin and Louise Cotnoir interrupts the history of iconic representation of Woman using words to reframe, by redirecting attention to, the cultural coding of meanings of the female body as art object, defamiliarizing the images of women, disrupting the iconicity of the visual sign, exposing its mediation in the male gaze. "Vidéoclip ou Psyché ranimée par le baiser de l'Amour" plays with framing, focusing on the blurring of boundaries/bodies, of foreground and background in the sculpture, while imitating this syntactical play in the abolition of grammatical sequence and punctuation in a flux of prose lines. "Variantes" plays with framing in another way, the brief poems providing a critical gloss on and a variation upon a sculpture or painting while the footnote at the bottom of the page identifies the male artist of the tableau that has been reworked. The white space between is the interval of the turn or swerve effected by the female gaze with its different angle of vision. The work of gender as a frame constituting meaning through 
its regulation of inside and outside, its forceful exclusions, is exposed in Sharron Margaret Turner's "Anxiety of Influence," which rewrites Harold Bloom's version of an oedipal family romance in the agon of father and son, to expose the way such a symbolic order has positioned woman as non-human, as animal, outside the lineage of symbolic production, outside the literary and painterly traditions of meaning making.

Interruption is the major point of Christine Davis's "Insert" which puts the female body into the double networks of visual and verbal signification. The female body is forced into the midst of the book (or is she escaping from it? or trampling on it sacrilegiously?) to foreground the mediation of the body and gender in the production of meaning through the operations of metonymy or contiguity. The angle of vision is a distorted one: this is not the classical symmetry of the "beautiful" female body, but a truncated version, without the all-meaningful trunk or torso and its marks of sexual difference, from the oblique and precarious angle of self-portraiture. The weight and contingency of the body and the book propose another angle on the history of representation. It is the converse interruption that Rachel Zolf's concrete poem performs, staging the iconic power of words in tension with their linearity and referential potential. Emphasizing the materiality of words on the page, Zolf displays the operation of the social contract, a sacrificial one that prohibits or scapegoats woman. The cross as icon of this social ritual doubles and augments the poeticity of the title which points out the fact that a woman is not a person, that a mimetic image or mask of woman is not that woman. Nor woman that mask. Foregrounding in this way the indeterminacy of the verbal sign and the problematics of reference, this text also plays with the grammar of reading, disrupting our habits of moving from left to right and top to bottom, to focus on typography spread across space apprehended simultaneously not consecutively. Perceptual sequence is made a sphere of free play exposing the mediating work of the "reading" eye. Here form=content in a way that undercuts the symbolic properties of language to force our awareness of these properties as convention and, as such, subject to the mediation of gender in the production of meaning. The movement to achieve presence in the text in the turn to iconicity, is destabilized by the tension introduced by this underlining of its semiotic, mediated nature.

This tension is played out in other ways in the two essays which focus on "phototextual narratives." Belén Martin Lucas borrows this term 
from Linda Hutcheon to examine the doubled perspectives of two composite texts by Canadian women that superimpose verbal narrative and photograph. Still Sane began as a series of texts moulded on the body to mimic the scarring of the body through the physical and emotional pain of medical practices to annhiliate lesbianism. These graffiti or hieroglyphs were subsequently photographed and printed in a book facing a collection of texts written about the process of "coming out," personal texts such as diary entries or letters to friends, often handwritten. Private/public, abnormal/normal, desire/pain are all topoi introduced in this text, their opposition restaged and reworked in the dialogic mode of layering, that is both critique of and creative alternative to the dominant symbolic order of the phallus and its regulation of a singular system of representation and desire. Diane Schoemperlen's Double Exposures foregrounds the textual method of dual sign systems, the interference that draws attention to their connotative proliferation productive of ambiguity as "signs of reality." Working with family photographs, as Lucas shows, she positions them as "documents," a proof of veracity, then undermines the truth-claims of their iconicity through a narrative that highlights the necessity of interpretation to ascertain "the facts" so concretely "proved." Interpretation from hindsight is highly problematic, however, the twists and turns of memory serving to mingle "reality" and "fiction" in the narrative. The instablity of both verbal and visual signs is foregrounded here in what becomes a highly "speculative" narrative, not unveiling the truth of the past but hypothesizing meanings for the future.

It is just this speculative turn to verbal narrative to fill in the gaps of the silent image that Susan McGahan examines and overturns in "Cleavages, or Mauve Desert as a Post-Structuralist Feminist Mystery Novel." In this reading of Nicole Brossard's novel, McGahan examines its tripartite structure around the folder of photographic images of "longman," never identified by the hermeneut in search of meaning, the private investigator tracking down clues, trying to solve the mystery of Angela's death, the feminist scrutinizing gendered discursive practices. The opaqueness of the visual sign is foregrounded here: all the verbal narrative produced by Brossard around the transcoding or translation from one sign system to another fails to solve the mystery, to reveal "the" truth. What it does, however, is to spin a narrative of the relations of desire and meaning-making between women. This engages the feminist critic as private investigator in an examination of the operations of desire 
and a scrutiny of her own meaning-making systems. What results is another triptych, one which begins with the thread of narrative exploring the cleavages or silences in a text where the visual image fails to speak itself and ends, through a metaphoric connection or translation, with an exploration of another kind of cleavage, the cleavage between women's breasts. The space between, interstice where desire surges forth, a space marked in McGahan's text by a movement into photography, into photographs of women's breasts shared among women friends and of their graffiti writing on the body, on the photographic image. A proliferation of signs on all surfaces.

Surface effects not reality effects are what Shonagh Adelman's images produce. Writing on the body this is. A palimpsest, however, a trace over the body of the photographic image, not a tattoo cut into the skin/screen. Such superposition of heterogeneous sign systems runs interference in their consumption. While the eye traces the outline of letters, then follows the letters across the page, it cannot globally apprehend the photographic images of bodily parts. This dispersion of the gaze inhibits its fixing on the body, perturbs the conjugation of subject with object of desire, defers voyeuristic pleasure. Postpones the pornographic "hit." In its place, it offers another affect, a dizzying one, from the "procedure" of "coupling" of "heterogeneous series." Their conjunction is a dynamic one: "Something 'crosses' between the edges; events explode, phenomena flash like lightning or thunder." There is both "resonance" from the pairing within seeming heterogeneity and "the amplitude of forced movement that spills beyond them" (Deleuze 1968, 155). One code or movement is set aslant by another in what functions as an "intensive system," telescoping signifiers or objects, multiplying or ramifying their resonance to infinity. Such a system produces the word or visual sign as gesture of an idea, as figure, permitting the resulting paradox to be actualized in a way that proliferates new ambiguities, branches out in multiple new series. These transformations in regimes of signification involve questions of accentuation or rhythm ordering different magnitudes in the double economy of sign systems whose discontinuity and diagonal encounter produce a displacement at the heart of "reading" the text which sets up surface events, sorties, lines of flight.

Consideration of the horizontal tendencies of such a clash of heterogeneous series is the focus of Barbara Sternberg's discussion of her work in "Shifting Realities." In this interview, she explains her editing of a succession of images in "Tending Toward the Horizontal," as these are 
intercut with a poem by France Daigle which focuses on movement and repetition in the process of making meaning in chains of verbal signifiers. What happens in the coupling of Daigle's poem and Sternberg's shots is that logical conjunctions operative in a temporal image are subordinate to a movement image that represents time indirectly as a succession of frames, a virtual becoming, not a simultaneity, but a potential that calls into question the notion of "truth" (Deleuze 1985, 360), because of its ability to break through boundaries and effect metamorphoses. Such serialism operates through horizontal organization, through linkages of contiguity. Contemporary images are produced under the aegis of "irrational cuts" or "incommensurabilities" between sign systems as looping (Deleuze 1985, 362). The interstice or interval, space of boundary play introducing change or innovation, is preeminent in the disjunction of sound (verbal) and visual images in the film (Deleuze 1985, 363). Sternberg describes her editing practice where she worked to eliminate synchronicity of verbal and visual images with its tendency to reinforce both as signs of "reality," choosing to explore instead the explosive potentials of the edge, working on questions of repetition, series, rhythm, the place where one thing moves into another.

While not necessarily implicating gender, such forays draw attention to the work of mediating images, of apprehending "reality," highlighting the way in which a shift in the angle of viewing produces a different "take" on "reality." Sternberg comes to this work of repetition, intensification, rhythm through the writing of Gertrude Stein for whom such a reversal of perspective is possible only for women who have historically been excluded from the conventions of viewing and ordering. Moreover, serialism is a kind of indefinite experimentation that dismantles arrangements, an intensification producing a resonating disequilibrium that becomes an active force of deformation and recombination within social protocols of representation, setting the system careening off track. This forces a reorganization within a regime of signs, realigning the networks of signifiers, instituting transformations of the language acts that allocate subjects and signs their positions within an order of social obligations, within specific relations of law and desire, to introduce lines of variation, lines of potential metamorphoses, a dispersion of points of "subjective" observation throughout images of movement. Lines of escape in which may be ordered a virtual woman.

In the following texts, such dispersions and becomings are staged in the slippage of verbal and visual signs as they stain rhetoric a different colour. 


\title{
Colorier la rhétorique
}

\author{
Barbara Godard
}

Appliquer? Impliquer? Comment tracer le plan des interactions des signes verbaux et visuels? S'agit-il des relations de référence, de figuration ou de typologie? Est-ce que les images illustrent des textes faisant accroître la force référentielle des mots? Dans la juxtaposition, les réclamations à la verité de la peinture-miroir prêteront un effet du réel à l'écriture. Où est-ce que c'est plutôt les mots qui arrêtent le sens de l'image visuelle polysémique, la chargeant des valeurs culturelles (Barthes 26)? Quand les images verbales et visuelles coexistent dans le même texte, est-ce que l'une fonctionne comme le référent de l'autre, ou est-ce que l'une de ces modalités de perception prévaut sur l'autre? La rhétorique est-elle coloriée pour que les mots se font regarder iconiquement comme des objets picturaux et les lignes et les couleurs se font lire indexiquement par rapport à un objet? Quel glissement sémiotique s'ensuit? Quelles modalités liminales s'impliquent dans cette lecture d'un type du signe à travers un autre, ce passage entre signes? Y a-t-il une différence si la plume ou l'oeil est dirigé par une femme? Quelle est la couleur de sa parole à elle (Tostevin)?

Des questions de ce genre sont à l'ordre du jour dans les milieux culturels contemporains caracterisés par "l'oculocentrisme": les sociétés modernes et postmodernes ont privilégié le regard pour produire des régimes scopiques multiples (Gandelman 151). L’hégémonie de l'oeil se manifeste dans l'importance accrue dans le vingtième siècle de l'analogie vénérable comparant la peinture à la poésie à la suite de la préoccupation des romantiques avec les facultés expressives de l'art plutôt qu'avec son mimétisme. En se raffirmant, cependant, l'analogie s'inverse: on ne souligne plus la capacité de l'art de refléter la vie mais on présente la dialectique de la représentation artistique et le monde représenté pour souligner le "statu paradoxal" des mots et des images visuelles comme "signes du réel" (Steiner xii). Une attention accrue portée au double statu du mot comme forme pure et comme moyen de 
production du sens a produit en même temps une concentration sur la matérialité du langage en tant que res poetica et le contraire, une mise en valeur de la médiation sémiotique des images visuelles qui ne sont plus prises pour "le vrai," "le naturel." Enchaînés dans un "contexture continue" (Steiner 7) ces signes aesthétiques sont reliés d'une manière dynamique.

Les signes visuels et verbaux s'imbriquent de plusieurs façons dans les textes réunis pour Tessera. La texture verbale des textes en prose et en poésie de Claudine Potvin et de Louise Cotnoir interrompt l'histoire de la représentation iconique des femmes: ils déploient les mots pour réencadrer, en attirant l'attention à, l'encodage culturel du corps féminin en tant qu'objet d'art, produisant ainsi de la distanciation, déstabilisant l'iconicité du signe visuel, exposant la médiation du regard masculin. "Vidéoclip ou Psyché ranimée par le baiser de l'Amour" bascule les distinctions entre l'avant-plan et l'arrière-plan de la sculpture tout en mimant ce jeu de limites dans l'absence de la ponctuation pour produire un flux de mots. "Variantes" joue avec l'encadrement autrement. Les poèmes constituent un supplément, un commentaire sur et une variation sur une sculpture ou une peinture. Les notes en bas de page indiquent le nom de l'artiste masculin dont le tableau a été retravaillé au féminin. L'espace blanc entre les deux est l'interval où se produit le tour ou l'écart du regard féminin avec son angle de vue différent. Le travail de la sexuation dans la production du sens par la régulation de l'intérieur et de l'extérieur d'un discours, dans ses pratiques d'exclusion, est mise en relief dans "Anxiety of Influence," de Sharron Margaret Turner, un texte qui réécrit le roman d'oedipe identifié par Harold Bloom dans la lutte entre père et fils qui constitue la tradition littéraire, pour exposer comment un tel ordre symbolique a posé la femme comme non-être, comme un animal, en dehors de la lignée de la production symbolique, en dehors des conventions traditionelles de représentation littéraire et artistique.

Interrompre, intervenir, c'est le but de "Insert" de Christine Davis qui place le corps de la femme dans les doubles réseaux de la signification visuelle et verbale. Le corps de femme est coincé au milieu du livre (ou est-ce qu'elle s'en évade? ou écrase sous ses pieds en sacrilège?) pour souligner la médiation du corps et du genre dans la production du sens dans les opérations de la métonymie ou de la contiguité. L'angle de vue est déformé, déformant: on ne voit pas le corps de femme de beauté symmétrique et classique, mais un corps coupé sans torse avec ses 
marques de la différence sexuelle, et photographié de l'angle oblique de l'auto-portrait. Le poids et la contingence du corps ouvre un regard autre sur l'histoire de la représentation. Le poème concrète de Rachel Zolf intervient dans une façon opposée, jouant de la paradoxe des capacités iconiques des mots en tension avec leur potentiel référentiel. Accentuant la matérialité des mots sur la page, Zolf manifeste l'enjeu du contrat social, un contrat sacrificiel pour les femmes. La croix comme signe iconique du rite de l'exclusion dédouble la poéticité du titre qui indique qu'une femmen'est pas une personne et qu'une masque ou image mimétique n'est pas une femme. Ni la femme cette masque. Ici l'équation la forme = le contenu mine les propriétés symboliques du langage et nous les présente comme des conventions sociales, ainsi, sujettes à la médiation sexuée dans la production du sens.

La tension entre l'iconicité comme présence et l'aspect sémiotique des signes se déploie autrement dans deux essais sur les "récits phototextuels." Belén Martin Lucas emprunte ce terme de Linda Hutcheon pour analyser les doubles réseaux dans deux textes des écrivaines canadiennes qui superposent un récit verbal et des photographes. Still Sane commençait par des textes moulus dans le corps pour mimer les cicatrices produites par la douleur physique et psychique des pratiques médicales pour éliminer le lesbianisme. Ensuite, ces graffitis étaient photographiés et imprimés dans un livre en face des textes écrits sur le processus de "coming out," des lettres à des amies ou des fragments d'un journal, écrits à la main. La superposition retravaille les oppositions binaires entre privé/publique, abnormale/normale, désir/douleur pour produire une critique et une réponse à la symbolique règlée par le phallus dans un système unaire du désir et de la représentation. Double Exposures de Diane Schoemperlen met en relief l'intérruption dans les systèmes de représentation double qui accentue la prolifération connotative ce qui les rendent ambigues comme "signes du réel." Elle travaille avec des photos de famille qu'elle avance comme des "documents," comme des preuves des "événements," pour ensuite miner les effets du réel de cette iconicité par un récit qui souligne la necessité de l'interprétation pour déduire les "faits" si concrètement "prouvés." Cependant, l'interprétation après les événements se révèle hasardeuse, car les détours de la mémoire mélange le réel et la fiction. L'instabilité des signes visuels autant que des signes verbaux est soulignée dans ce récit "spéculatif."

La spéculation du spéculaire est précisément le sujet de l'essai de Susan McGahan, "Cleavages, or Mauve Desert as a Post-Structuralist 
Feminist Mystery Novel." McGahan examine la structure triple du roman de Nicole Brossard qui tourne autour des photos du "l'homoblong" qui n'est jamais identifié pourtant par cette herméneute en quête du sens, cette détective sur la piste du meurtrier (?) d'Angela, par cette féministe scrutant les pratiques discursives sexuées. L'opacité du signe visuel est soulignée, car tout ce que le récit de Brossard produit sur le transcodage des signes (la traduction) ne résoudre pas le mystère, ne produit pas la vérité. Mais le récit tisse les relations du désir et les opérations de faire sens dans un réseau des femmes. La critique féministe se penche alors sur le désir et sur ses propres pratiques de faire sens. Cela aboutit à la production d'un deuxième triptyque, l'essai, qui commence par un fil narratif explorant les failles ou les silences du texte, là où l'image visuelle ne parle pas, et se termine à travers une traduction "métaphorique" avec l'exploration d'un autre clivage, celui entre les seins des femmes. L'interstice d'où surgit le désir pour un texte d'une femme se situe dans un mouvement vers la photographie. Des photos des seins des femmes sont échangées entre amies qui écrivent sur leur corps, sur les photos... Une prolifération des signes sur toutes les surfaces.

Des effets de surface et non pas des effets du réel sont produits par les images de Shonagh Adelman. C'est une écriture sur le corps. Un palimpseste, cependant, une marque sur le corps de l'image photographique, non pas un tatouage piqué dans un corps/écran. Cette superimposition des systèmes de signes hétérogènes empêche leur consommation facile. Tandis que l'oeil trace les grands traits des lettres, les suit à travers la page, il ne peut pas saisir globalement les images photographiques du corps féminin. Le regard ainsi dispersé ne peut pas se fixer sur le corps: la conjugaison du sujet avec l'objet du désir est dérangée, le plaisir du voyeur déféré. Le "coup" pornographique déjoué. Un autre effet se produit, vertigineux, dans la conjoncture dynamique des "séries hétérogènes." Quelque chose traverse les frontières et tout éclate. Il y a à la fois une résonance dans la conjugaison et l'amplitude d'un mouvement forcé qui se déferle. Un code est mis à travers par un autre produisant un "systéme intensif," téléscopant les signifiants, les ramifiants jusqu'à l'infini (Deleuze 1968, 155). Ces transformations dans des régimes de signification provoquent des questions del'accentuation ou du rythme qui ordonnent des grandeurs différentes dans une économie double des systèmes du signe dont la rencontre en diagonale effectue un déplacement au "coeur" de la lecture d'un texte ce qui produit des événements de surface, des sorties, des lignes de fuite. 


\section{Tessera}

Une réflexion sur les tendances horizontales d'une telle confrontation des séries hétérogènes est offerte par Barbara Sternberg dans "Shifting Realities." Dans cet entretien, elle décrit le travail de montage d'une succession d'images visuelles avec le poème "Tending Toward the Horizontal" par France Daigle, un poème qui travaille la question de la répétition et le mouvement dans la production du sens verbal. Dans l'alliance des mots de Daigle avec les clichés de Sternberg les conjunctions logiques de l'image temporelle se subordonnent à une image du mouvement qui représente le temps indirectement comme une suite d'images qui n'est pas une simultanéité mais un devenir virtuel, une potentialité qui interroge la notion même de la "vérité" en ce qu'elle dépasse les limites pour produire des métamorphoses. L'organisation des séries se fait en général horizontalement instaurant le règne des "incommensurabilités" ou des "coupures irrationnelles" qui introduisent l'interstice ou l'intervalle comme l'espace de transformation, un espace ouvert par la disjonction entre l'image visuelle et l'image verbale du film (Deleuze 1985, 361-3). Sternberg décrit comment elle cherche à éviter la synchronicité des deux systèmes dans le montage, travaillant plutôt sur les bords, les limites, par des stratégies de répétition, de sérialisation. Elle interroge ainsi le point où quelque chose se transforme en autre chose, l'entre-deux.

Bienqu'elles n'impliquent pas nécessairement la sexuation du discours, de telles sorties mettent en relief la médiation des images par où l'on "saisit" le réel. Sternberg aborde ce travail du rythme, de l'intensification, par l'oeuvre de Gertrude Stein pour qui un changement radical de la perspective n'est possible que pour une femme qui a été tenue à l'écart des conventions de regard et de disposition. De plus, le sérialisme est une sorte d'expérimentation interminable qui démonte les dispositifs discursifs, une intensification produisant un déséquilibre qui déforme et recombine les protocoles sociaux de la représentation. Cela force une réorganisation dans un régime des signes donné, un réalignement du réseau des signifiants, ce qui transforme des actes langagiers par où des sujets et des signes sont disposés dans un ordre d'obligations sociales. Dans une économie du désir spécifique, cela produit des variantes, des lignes de métamorphose potentielle, une dispersion des points du regard dans des images-mouvement. Des lignes de fuite par où produire une femme virtuelle.

Dans les textes réunis ici, de tels dispersions et devenirs se produisent dans un glissement des signes verbaux et visuels quand ils teintent la rhétorique une couleure différente. 


\section{Works Cited}

Barthes, Roland. "The Photographic Message." Image, Music, Text. Trans. Stephen Heath. London: Fontana, 1977.

Deleuze, Gilles. Différence et répétition. Paris: PUF, 1968.

Deleuze, Gilles. Cinéma 2: l'image-temps. Paris: Minuit, 1985.

Gandelman, Claude. Reading Pictures, Viewing Texts. Bloomington: Indiana U P, 1991.

Kristeva, Julia. Histoires d'amour. Paris: Denoël, 1983.

Kristeva, Julia. Au commencement était l'amour: Psychanalyse et foi. Paris: Hachette, 1985.

Parker, Alice. "Le mal de mere/The (M)Other's Text." Tessera 14, 1993.

Steiner, Wendy. The Colours of Rhetoric. Chicago: U Chicago P, 1982.

Tostevin, Lola Lemire. Colour of Her Speech. Toronto: Coach House, 1982. 